akceptując taki jej rodzaj, jaki Mu zadano. Jego ciało umiera na krzyżu, ale nie przestaje być własnym Ciałem Logosu, nie oddziela się od niego, nawet zstępując do otchłani.

Autor podsumowuje ten rozdział wracając do koncepcji duszy i powtarzając, że u Atanazego Logos jest życiem każdego człowieka, nie tylko Jezusa. Nie potrzeba zajmować się filozoficzną duszą; zostawmy ją filozofom i psychologom. Prawda, że dusza dostała się do katechizmu i prawd wiary, ale to Atanazy ma rację: to co filozofowie nazywali duszą, bo nie doszło do nich objawienie, to w rzeczywistości jest działający Logos, w Jezusie i w każdym innym. Uważam, że książka ks. P.M. Szewczyka należy do najważniejszych prac patrologicznych ostatnich lat.

Henryk Pietras SJ - Kraków, WSFP „Ignatianum”

\title{
Theofried BAUMEISTER, Martyrium, Hagiographie und Heiligenverehrung im christlichen Altertum, Römische Quartalschrift für Christliche Altertumskunde und Kirchengeschichte. Supplementband 61, Rom - Freiburg - Wien 2009, Herder, ss. 352.
}

Profesor Th. Baumeister przeszedł na emeryturę 30 września 2009. Przez 33 lata (od roku 1976) był profesorem historii Kościoła w starożytności, patrologii i archeologii chrześcijańskiej w uniwersytecie Jana Gutenberga w Moguncji. W ten sposób osiągnął wiek Chrystusowy na stanowisku profesora uniwersyteckiego. Domeną szczególnej aktywności badawczej Autora była hagiografia i koptologia (jego naukowy życiorys por. http://de.wikipedia.org/wiki/ Theofried_Baumeister).

W niecały miesiąc po przejściu w stan oficjalnego, uniwersyteckiego spoczynku, ukazała się powyższa, bardzo starannie wydana publikacja. Jest ona zbiorem 28 artykułów Profesora, które ukazały się wcześniej w różnych, niekiedy trudno dostępnych (szczególnie polskiemu czytelnikowi) czasopismach lub pracach zbiorowych (wyjątek stanowią tutaj dwie publikacje zamieszczone w prezentowanym zbiorze: $\mathrm{nr}$ 11: Konstantin der Große und die Märtyrer, s. 113-137; tylko część tego tekstu została przedstawiona w formie referatu na Kongresie Patrystycznym w Oksfordzie, 6-11 sierpień 2007; oraz nr 22: Die Entstehung der Märtyrerverehrung, s. 260-268; dotąd istniała tylko wersja polskojęzyczna tego artykułu-Początki kultu męczenników, PzST 6:1986, s. 261-270). Rzecz owa jest autorskim wyborem publikacji, który to wybór stanowi swego rodzaju podsumowanie dotychczasowych dokonań Prof. Th. Baumeistra w zakresie określonym tytułem prezentowanego tutaj zbioru. W ten sposób Autor postarał się niejako na pożegnanie oddać w ręce czytelnika wybór najbardziej jego zdaniem znaczących wyników swych dotychczasowych badań nad historią wczesnego chrześcijaństwa w aspekcie męczeństwa, hagiografii i kultu świętych. O ich intensywności świadczy bibliografia prac Th. Baumeistra, zamieszczona w omawianej publikacji 
(s. 327-342), która obejmuje lata 1968-2006 i stanowi swego rodzaju wartość dodatkowa tego retrospektywnego zbioru dokonań Autora.

Wspomniane wyżej artykuły zostały podzielone na trzy monotematyczne części. Każda z nich nosi bardzo lakoniczny i łatwy do zapamiętania hasłowy tytuł: 1) Martyrium (s. 9-137) - zawiera 11 ułożonych według klucza chronologicznego (chodzi nie o chronologię powstawania artykułów, lecz o chronologię analizowanych w nich zdarzeń historycznych); noszą one numery od 1 do 11.2) Hagiographie (s. 139-230) - zawiera 8 wcześniejszych publikacji, ułożonych według tego samego klucza; noszą one numery od 12 do 19.3) Heiligenverehrung (s. 231-325), na co złożyło się z kolei 9 artykułów, oznaczonych cyframi od 20 do 28. Całość zbioru układa się w ten sposób w logiczną, spójną całość: 1). śmierć męczeńska, 2). przekaz o niej, 3). kult jako konsekwencja dwóch wcześniejszych zdarzeń. Analizowanie pracy ułatwia zamieszczony na jej końcu Register (s. 345352). Rozprawa nie posiada niestety osobnego wykazu bibliograficznego, co przy bardzo bogatej liczbie publikacji cytowanych w przypisach sprawia pewien kłopot. Mankament ten jest jednak niemal naturalną konsekwencją tego, że jest to wybór bazujący na wcześniejszych dokonaniach Autora. Brak ten rekompensuje jednak w znacznym stopniu monograficzny charakter publikacji, wchodzących w skład zbioru. W konsekwencji ich przypisy podtekstowe stają się dla czytelnika źródłem konkretnych, monotematycznych wskazówek bibliograficznych. Brakiem trudniejszym do zrekompensowanie, szczególnie w przypadku chociażby czytelnika polskiego, jest brak wykazu skrótów. Autor informuje tylko we wstępie (s. 7), że abrewiacje użyte w tekście i w bibliografii pochodzą z trzeciego wydania Lexikon für Theologie und Kirche.

Wybór 28 artykułów to niewiele ponad 10 procent dotychczasowego dorobku Autora. Składają się na niego: A) monografie (5); B) artykuły (ponad 100); C) hasła słownikowe (ponad 100), pisane przede wszystkim dla The Coptic Encyclopedia, Handwörterbuch der antiken Sklaverei, Lexikon der antiken christlichen Literatur (wyd. 1-3), Lexikon des Mittelalters, Lexikon für Theologie und Kirche (wyd. 3) oraz Religion in Geschichte und Gegenwart (wyd. 4); D) recenzje (około 100).

Ponieważ praca, z wyjątkiem jednego wspomnianego wyżej artykułu, jest retrospektywnym zbiorem publikacji, warto dodać do powyższego jej omówienia swego rodzaju konkordancję, którą zresztą naszkicował już sam Autor, podając na początku każdej części swego wyboru proweniencję danego artykułu. Zestawienie to może do pewnego stopnia ułatwić badaczom zainteresowanym tematyką męczeństwa we wczesnym chrześcijaństwie orientację w bibliografii profesora Theofrieda Baumeistra oraz zrekompensować wspomniany wyżej brak wykazu skrótów.

I. Martyrium. 1. s. 11-21: Märtyrer und Martyriumsverständnis im frühen Christentum: Ursprünge eines geschichtsmächtigen Leitbildes $(=$,Wissenschaft und Weisheit" 67:2004, s. 179-190); 2. s. 22-28: Anytos und Meletos können mich zwar töten, schaden jedoch können sie mir nicht" . Platon, Apologie des Sokrates 30c/d 
bei Plutarch, Epiktet, Justin Martyr und Clemens Alexandrinus (w: Platonismus und Christentum. Festschrift H. Dörrie, hrsg. H.D. Blume - F. Mann, Münster 1983 $=\mathrm{JbAC}$ Ergänzungsband 10, s. 58-63); 3. s. 29-40: Das Martyrium in der Sicht Justins des Märtyrers (= StPatr 17/2:1982, s. 631-642); 4. s. 41-49: Die Norm des evangeliumgemäßen Blutzeugnisses. Das Martyrium Polycarpi als vorsichtige Exhortatio ad Martyrium (w: Stimuli. Exegese und ihre Hermeneutik in Antike und Christentum. Festschrift E. Dassmann, hrsg. G. Schöllgen - C. Scholten, Münster $1996=$ JbAC Ergänzungsband 23, s. 122-128); 5. s. 50-65: Der Brief der Gemeinden von Vienne und Lyon und die Offenbarung des Johannes (w: Studien zur Johannesoffenbarung und ihrer Auslegung. Festschrift O. Böcher zum 70. Geburtstag, hrsg. F.W. Horn M. Wolter, Neukirchen - Vluyn 2005, s. 339-355); 6. s. 66-70: Zur Datierung der Schrift an Diognet (= VigCh 42:1988, s. 105-111); 7. s. 71-79: Das Martyrium als Thema frühchristlicher apologetischer Literatur (= Martyrium in Multidisciplinary Perspective. Memorial L. Reekmans, ed. M. Lamberigts - P. Van Deun, Leuven 1995, s. 323-332; 8. s. 80-90: Martyrium - Mönchtum - Reform. Tertullian und die Vorgeschichte des Mönchtums, (w: Reformatio Ecclesiae. Beiträge zu kirchlichen Reformbemühungen von der Alten Kirche bis zur Neuzeit. Festgabe E. Iserloh, hrsg. R. Bäumer, Paderborn 1980, s. 23-34); 9. s. 91-106: Die montanistischen Martyriumssprüche bei Tertullian (= RQ 101:2006, s. 157-172); 10. s. 107-112: Der ägyptische Bischof und Märtyrer Phileas (w: Garten des Lebens. Festschrift W. Cramer, hrsg. M.B. von Stritzky - Ch. Uhrig, Altenberge 1999, s. 33-41); 11. s. 113137: Konstantin der Große und die Märtyrer (tekst ten nie był dotąd nigdzie publikowany. Jego część została natomiast przedstawiona w formie referatu na Kongresie Patrystycznym w Oksfordzie, 6-11 VIII 2007).

II. Hagiographie. 12. s. 141-152: Die koptischen Märtyrerlegenden (w: Märtyrer und Märtyrerakten, hrsg. W. Ameling, Stuttgart 2002, s. 121135); 13. s. 153-158: Fortschritte in der ägyptischen Hagiographie (w: Divitiae Aegypti. Koptologische und verwandte Studien zu Ehren von M. Krause, hrsg. C. Fluck, Wiesbaden 1995, s. 9-14); 14. s. 159-173: Der Martyrer Philemon (w: Pietas. Festschrift B. Kötting, hrsg. E. Dassman - K.S. Frank, Münster $1980=$ JbAC Ergänzungsband 8, s. 267-279); 15. s. 174-183: Die Historia monachorum in Aegypto und die Entwicklung der koptischen Hagiographie (w: Coptic Studies on the Threshold of a New Millennium, Proceedings of the Seventh International Congress of Coptic Studies, [Leiden, 27 VIII - 2 IX 2000, ed. M. Immetzeel - J. van der Vliet, Leuven 2004, s. 269-280); 16. s. 184-195: Ägyptisches Lokalkolorit in der Historia monachorum in Aegypto (w: Aegyptus christiana. Mélanges d'hagiographie égyptienne et orientale dédiés à la mémoire du P.P. Devos, red. U. Zanetti - E. Lucchesi, Genève 2004, s. 165-174); 17. s. 196-211: ̈̈gyptisches Lokalkolorit im monastischen Schriftum des Johannes Cassianus (w: Europa und die Welt in der Geschichte. Festschrift zum 60. Geburtstag von D. Berg, hrsg. R. Averkorn, Bochum 2004, s. 433-446); 18. s. 212-216: Der heilige Bischof. Überlegungen zur Vita Cypriani $=$ StPatr 18/3:1989, s. 275-282); 19. s. 217-230: Der Rekurs 
auf die Bibel als Mittel zur Darstellung heiliger Geschichte in der altchristlichen Hagiographie (w: Normieren, Tradieren, Inszenieren. Das Christentum als Buchreligion, hrsg. A. Holzem, Darmstadt 2004, s. 55-71).

III. Heiligenberehrung. 20. s. 233-250: Die Entstehung der Heiligenverehrung in der Alten Kirche (w: Heiligenverehrung - ihr Sitz im Leben des Glaubens und ihre Aktualität im ökumenischen Gespräch, hrsg. G.L. Müller, München 1986, s. 9-30); 21. s. 251-259: Zeugnisse der Mentalität und Glaubenswelt einer vergangenen Epoche. Hagiographische Literatur und Heiligenverehrung in der Alten Kirche (w: Kriminalisierung des Christentums? Karlheinz Deschners Kirchengeschichte auf dem Prüfstand, hrsg. H.R. Seeliger, Freiburg im Breisgau 1994², s. 267-279); 22. s. 260-268: Die Entstehung der Märtyrerverehrung (artykuł ten ukazał się wcześniej tylko w wersji polskojęzycznej - Początki kultu męczenników, PzST 6:1986, s. 261-270); 23. s. 269-275: Vorchristliche Bestattungssitten und die Entstehung des Märtyrerkultes in Ägypten (= RQ 69:1974, s. 1-6 + Tafel 1); 24. s. 276-283: Das Stephanuspatrozinium der Kirche im ehemaligen Isis-Tempel von Philae, (= RQ 81:1986, s. 187-194); 25. s. 284-292: Der heilige Theodor in Nubien (w: Nubische Studien. Tagungsakten der 5. internationalen Konferenz der International Society for Nubian Studies [Heidelberg, 22.-25. IX 1982], hrsg. M. Krause, Mainz 1986, s. 211-216 + Abb. 1); 26. s. 293-304: Nordafrikanische Märtyrer in der frühen römischen Heiligenverehrung (= RQ 98:2003, s. 35-46); 27. s. 305-319: Die christlich geprägte Höhe. Zu einigen Aspekten der Michaelsverehrung (= RQ 83:1988, s. 195210); 28. s. 320-325: Religionsgeschichtliche und kultgeographische Aspekte der westlichen Michaelsverehrung, (w: Memoriam sanctorum venerantes. Miscellanea in onore di Monsignor V. Saxer, Città del Vaticano 1992, s. 11-19).

Piotr Kochanek - Lublin, KUL

\section{Danuta MASTAlSKA, Śpiew anioła. Powieść o św. Cecylii, Tarnów 2009, Biblos, ss. 385.}

Refleksja nad powieścią historyczną, czerpiącą swe inspiracje z okresu wczesnego chrześcijaństwa, ma już na łamach „Vox Patrum” swoją tradycję (por. A. Stępniewska, Ks. Hugo Koltataj o autorach wczesnochrześcijańskich, VoxP 6:1986, t. 11, 769-774; M. Starowieyski, Scena „Quo vadis”: Acta Petri, Martyrium 6, VoxP 17:1997, t. 32-33, 382-390; A. Stępniewska, Nie zrealizowana powieść Henryka Sienkiewicza o Julianie Apostacie, VoxP 17:1997, t. 32-33, 391397; B. Pawłowska, Pierwsi chrześcijanie a katakumby rzymskie w XIX-wiecznej i wspótczesnej polskojęzycznej powieści historycznej, VoxP 18:1998, t. 34-35, 455469; A. Stępniewska, Męczennicy wczesnochrześcijańscy w wykładach lozańskich A. ickiewicza, VoxP 6:1997, t. 10, 183-202). W ten kontekst wpisuje się również niniejsza recenzja powieści dr Danuty Mastalskiej. 